\title{
Use of pectin in the postharvest conservation of tangerine
}

\author{
${ }^{1}$ Plácido, G. R.*, ${ }^{2}$ Silva, R. M., ${ }^{3}$ Silva, M.A.P., ${ }^{2}$ Furtado, D. C., ${ }^{4}$ Santos, M. G., ${ }^{5}$ Caliari, M. and \\ ${ }^{6}$ Oliveira, D. E. C. \\ ${ }^{1}$ Department of Food Science and Technology, Federal Institute Goiás - Rio Verde Campus, CP 66, 75901-970, Rio \\ Verde, GO, Brazil. \\ ${ }^{2}$ Department of Food Engineering, Federal Goiás Institute - Campus Rio Verde, CP 66, 75901-970, Rio Verde, GO, \\ Brazil. \\ ${ }^{3}$ Department of Animal Science, Federal Institute Goiás - Rio Verde Campus, CP 66, 75901-970, Rio Verde, GO, Brazil. \\ ${ }^{4}$ Department of Food Science and Technology, Federal University of Goiás, CP 131, 74690-900, Goiânia - GO, Brazil. \\ ${ }^{5}$ Department of Food Science and Technology, Federal University of Goiás, CP 131, 74690-900, Goiânia - GO, Brazil, \\ ${ }^{6}$ Department of Agrarian Sciences - Agronomy, Federal Institute Goiás - Rio Verde Campus, CP 66, 75901-970, Rio \\ Verde, GO, Brazil.
}

\begin{abstract}
The aim of the present study was to evaluate the postharvest behavior of tangerine coated with different pectin concentrations during storage under controlled temperature $\left(22^{\circ} \mathrm{C} \pm 0.1\right)$. Fruits with green color ( $\pm 90 \%$ of the surface) were divided into four groups: fruits without any coating (T1) and fruits coated with pectin solution at $4 \mathrm{~g} / 100 \mathrm{~g}$ (T2), $6 \mathrm{ml} / 100 \mathrm{ml}$ (T3) and $8 \mathrm{~g} / 100 \mathrm{ml}$ (T4). Tangerines were evaluated during the storage period $(0,3,6,9,12$ and 15 days) for the following parameters: vitamin $\mathrm{C}$, soluble solids (SS), total titratable acidity (TTA), mass loss, turgidity pressure and external appearance through colorimetric analysis. In general, coated fruits showed lower mass loss over the storage period. The polynomial model was the model that best suited the experimental data. Regarding to the physicochemical characteristics, the citrus fruits and non-climacteric, showed little variation in the treatments and changes that have occurred and which can be explained by the variability of the fruits used. In general, the fruit treated with different concentrations of pectin kept green for longer period and with this feature of the fruits, is better accepted by the consumer.
\end{abstract}

Key words: Citrus deliciosa Tenore, pectin, coatings, coloring, mathematical models.

\section{INTRODUCTION}

Tangerine belonging to genus Citrus deliciosa Tenore is a citrus fruit originated from Asia. Trees that produce tangerines adapt to tropical and sub-tropical climates, have intermediate size and are thorny, with full and rounded crown formed by small leaves of dark green color.
It is considered a mid-season fruit, which is harvested primarily from May to June and due to seasonality, there is a need to extend its offer to other periods of the year (Nascimento et al., 2010). About 960 tons of tangerines are harvested annually in the country (IBGE, 2012). The quality characteristics of citrus fruit are of paramount 
importance for marketing, whether for fresh consumption or for juice processing. Attributes that are of relevance in postharvest quality as include appearance, flavor, odor, texture and nutritional value. Chitarra and Chitarra (2005) report that postharvest fruit quality is related to the minimization of the respiration rate, firmness, color, appearance, aiming at keeping them attractive to consumer for a longer period of time.

According to Miguel et al. (2009), fruits of strong and bright coloring are preferred by consumers, although it is not a factor that contributes to their nutritional value. Many storage techniques have been developed over the years to increase the shelf life of fresh fruits, which can be extended by the use of controlled and modified atmosphere and use of edible coatings (Togrul and Arslan, 2004). Despite the wide availability of synthetic packaging and functionality, there is difficulty in recycling, and this has encouraged investigators to develop biodegradable materials with functional characteristics that allow its use as packaging (Souza et al., 2012).

Edible coatings are biofilms prepared from biological materials that act as barriers to external elements by protecting the packaged product from physical and biological damage and increasing its shelf life (Henrique et al., 2008). Coatings have excellent barrier properties, especially against the transport of gases and water vapor, and other factors that contribute to maintaining the postharvest quality of fruits. Edible films can help providing firmness and shine to coated fruits (ValenciaChamorro et al., 2011).

Many studies with biofilms have been aimed at evaluating the physical and chemical quality of fruits and vegetables, among them: cassava starch in the conservation of sweet pepper; (Lemos et al., 2007) tomatoes coated with different pectin concentrations (Oliveira et al., 2012.); postharvest conservation of guavira coated with carboxy methyl cellulose, pectin and calcium chloride and pectin alone (Scalon et al., 2012.); tomatoes coated with FruitWax $\mathrm{H} 2$ carnauba wax, FruitWax M-AC emulsion resins and Meghwax carnauba wax (Chiumarelli and Ferreira, 2006); carnauba wax in the conservation of persimmon (Blum et al., 2008.); blackberry coated with cassava starch and water kefir grains (Oliveira et al., 2013). Despite the great diversity of biofilms used on fruits and vegetables, there is little information on the application of pectin-based biofilm on tangerines.

Pectin is of utmost importance in food technology and processing as it is associated with the function of providing firmness, flavor and aroma retention, as well to its role as hydrocolloid in the dispersion and stabilization of various emulsions (Gancz et al., 2006). Although, pectin extraction varies according to the raw material used, in general, the process comprises extraction of original vegetable in acid aqueous medium, purification of the liquid extracted and pectin isolation by precipitation (Christensen, 1984). The content of pectic substances varies according to the botanical origin of the plant material, four byproducts from agricultural and food industries rich in pectic substances (content above $15 \mathrm{~g} /$ $100 \mathrm{~g}$ dry basis): apple bagasse, citrus albedo, beet pulp and sunflower petals (Thibault, 1980). Above, the research aimed to evaluate the influence of coating the base of pectin in physical and chemical characteristics of mandarins (C. deliciosa Tenore) during storage.

\section{MATERIALS AND METHODS}

The study was conducted at the Laboratory of Fruits and Vegetables - Food Engineering sector, Federal Institute of Goiás Rio Verde Campus, and the colorimetric evaluation was performed at the Food Engineering sector, School of Agronomy, Federal University of Goiás (Goiânia).

\begin{abstract}
Materials
The fruits were harvested at its full physiological development $( \pm$ $90 \%$ of the surface), being obtained by manual harvesting in a farm

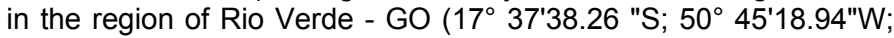
Altitude: $704 \mathrm{~m}$ ). Fruits were washed in running water, sanitized

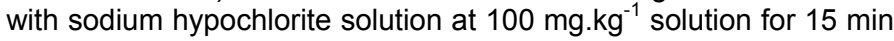
and dried with paper towel. Fruits were then randomly divided into four groups: tangerine with no coating, composing the control treatment (T1) and fruits coated with pectin solution at $4 \mathrm{~g} / 100 \mathrm{ml}$ (T2), $6 \mathrm{~g} / 100 \mathrm{ml}$ (T3) and $8 \mathrm{~g} / 100 \mathrm{ml}$ (T4).
\end{abstract}

\section{Preparation and addition of coatings}

Preparation of proposals for concentrations of the biofilm, we used the following amounts of commercial citrus pectin maker Dinâmica Química Contemporrânea Ltda (formulation $1 \mathrm{~L}$ ): $40 \mathrm{~g}$ (solution at 4 $\mathrm{g} / 100 \mathrm{ml}$ ); $60 \mathrm{~g}$ (solution at $6 \mathrm{~g} / 100 \mathrm{ml}$ ) and $80 \mathrm{~g}$ (solution at $8 \mathrm{~g} /$ $100 \mathrm{ml}$ ). Formulations were homogenized in a semi-industrial blender (Skymsen 15V-04) for $30 \mathrm{~s}$ until pectin gelation. After preparation, tangerines were immersed in different solutions $( \pm 1$ min) and placed in metal racks to dry naturally. Subsequently, they were placed on polystyrene trays for BOD storage with controlled temperature $\left(22 \pm 0.1^{\circ} \mathrm{C}\right)$ for $0,3,6,9,12$ and 15 days.

\section{Physical and chemical analyses}

Every three days of storage, whole fruits were submitted to turgidity pressure, by flattening technique using a horizontal leveler (Calbo and Nery, 1995) and to determine the mass loss of tangerines in each treatment three replicates were formed, and each repetition contained five fruits. The weight of the fruits was performed on an analytical balance CELTC FA 2104M, with results expressed in grams. We used the same fruits to evaluate the evolution of the mass loss during storage (AOAC, 2005), and after manual pulping, 
Table 1. Mathematical model applied for mass loss.

\begin{tabular}{ll}
\hline Model & Model designation \\
\hline Page & $P M=\exp \left(-k \cdot t^{n}\right)$ \\
Linear & $P M=k \cdot t$ \\
Modified Page & $P M=\exp \left((k \cdot t)^{n}\right)$ \\
Logarithm & $P M=a \cdot \exp (-k \cdot t)+c$ \\
Handerson and Pabis & $P M=a \cdot \exp (-k \cdot t)$ \\
Two Terms & $P M=a \cdot \exp \left(k_{0} \cdot t\right)+b \cdot \exp \left(k_{1} \cdot t\right)$ \\
Polynomial & $P M=k_{0}+k_{1} \cdot t+k_{2} \cdot t^{2}+k_{3} \cdot t^{3}$ \\
\hline
\end{tabular}

t: Storage time, days; $k, k_{0}, k_{1}, k_{2}, k_{3}$ : model constants, days ${ }^{-1}$; and a, b, c, n: model coefficients.

the following chemical analyses were performed: the vitamin $C$ content was determined according to the methodology described by Lutz Institute Adolf (1985) by titration with potassium iodide and the results expressed as $\mathrm{mg}$ vitamin $\mathrm{C} / 100 \mathrm{~mL}$ of juice, soluble solids based on direct reading refractometer Atago N-2E (ITB, 2005), the results being expressed in brix and the total acidity according to the methodology described by AOAC No. 942.15 (1997), by titration with $\mathrm{NaOH} 0.1 \mathrm{M}$ was determined, and the results expressed as $\mathrm{g}$ total acid / $100 \mathrm{~mL}$. For mass loss, fruits were numerically marked and weighed during storage.

\section{Color}

Tangerines were evaluated in terms of instrumental color parameters according to the CIELab system $L^{*}, a^{*}$ and $b^{*}$ in colorimeter (ColorQuest II, Hunter Associates Laboratory Inc, Virginia), where three distinct points were analyzed, totaling 24 points in each fruit. The results were expressed in $L$ *, $a$ * and $b$ * values, where $L$ * values (luminosity or brightness) ranged from black (0) to white (100), a * values from green $(-60)$ to red $(60)$, and $b$ * values from blue $(-60)$ to yellow (60).

\section{Mass loss}

From the experimental data obtained by the weight loss, they were adjusted to different equations shown in Table 1 commonly used to represent the rate of mass loss of agricultural products during storage. The use of different equations for mass loss study is relevant to have a higher precision.

\section{Statistical analyses}

Experiments were conducted in a completely randomized design (CRD) in $4 \times 6$ factorial scheme consisting of four treatments (control, 4, 6 and $8 \mathrm{~g} / 100 \mathrm{ml}$ pectin) and six storage times $(0,3,6$, 9,12 and 15 days) using software $\mathrm{R}$ (2014), where the analyzes were conducted in three replicates for each treatment, and each replicate consisted of 5 fruits, and each analysis was performed in triplicate for each repetition. The results were submitted to analysis of variance by $\mathrm{F}$ test and the comparison of means by the Tukey test at $5 \%$ probability. For statistical analysis of mass loss, mathematical models were fitted by nonlinear regression using the Gauss-Newton method and statistical software. The models were selected considering the magnitude of the determination coefficient $\left(R^{2}\right)$, Chi-square test $(X 2)$ and standard deviation of the estimate (SE).

$$
\begin{aligned}
& \mathrm{SE}=\sqrt{\frac{\sum(\mathrm{Y}-\hat{\mathrm{Y}})^{2}}{\mathrm{GLR}}} \\
& \chi^{2}=\frac{\sum(\mathrm{Y}-\hat{\mathrm{Y}})^{2}}{\mathrm{GLR}}
\end{aligned}
$$

Where, Y: value experimentally observed; $\hat{Y}$ : value estimated by the model; GLR: degrees of freedom (number of experimental observations minus the number of model coefficients).

The criteria used for selecting the model were the magnitude of the determination coefficient $\left(R^{2}\right)$, the lowest standard deviation of the estimate (SE) and the $\mathrm{X} 2$ value (chi-square).

\section{RESULTS AND DISCUSSION}

\section{Chemical characterization}

During storage, acids present in fruits are used as substrates for respiration, reducing their content. The titratable acidity values (Figure 1) showed small variations $(p \leq 0.05)$ as a function of treatments and storage time. In general, the vitamin $\mathrm{C}$ content (Figure 2) decreased as a function of the storage time all treatments. The applied coatings were used in an attempt to prevent the transfer of gases between atmosphere and fruit. Accordingly, coatings should help prevent the oxidation of vitamin $\mathrm{C}$ by preventing fruit exposure to oxygen and changing enzyme activity. However, samples showed statistically equal losses, with little or no variation. Azeredo et al. (2012) reported that acerola fruit coated with mixtures of nano-reinforced polymeric materials showed lower levels of ascorbic acid when compared to a single coating. Alleoni et al. (2006) also observed a slight change in TS and SS values in juice from orange coated with films based on milk whey protein concentrate. Arnon et al. (2014) reported that the TS and SS levels in juice are important parameters of internal quality in citrus and did not observe any significant effects 
Table 2. Mean determination coefficient $\left(R^{2}\right)$, standard deviation of the estimate and $x^{2}$ values for mathematical models of mass loss for coated tangerines.

\begin{tabular}{|c|c|c|c|}
\hline Model & $R^{2}(\%)$ & SE (decimal) & $x^{2}$ \\
\hline \multicolumn{4}{|l|}{$\mathrm{T1}$} \\
\hline Page & 98.94 & 1.20 & 1.45 \\
\hline Linear & 98.93 & 1.08 & 1.17 \\
\hline Modified Page & 98.94 & 1.20 & 1.45 \\
\hline Logarithm & 99.15 & 1.25 & 1.55 \\
\hline Handerson \& Pabis & 90.31 & 3.64 & $13.2 \varepsilon$ \\
\hline Two Terms & 90.31 & 5.15 & 26.56 \\
\hline Polynomial & 99.63 & 1.01 & 1.02 \\
\hline \multicolumn{4}{|l|}{ T2 } \\
\hline Page & 98.61 & 0.96 & 0.93 \\
\hline Linear & 96.01 & 1.46 & 2.12 \\
\hline Modified Page & 98.61 & 0.96 & 0.93 \\
\hline Logarithm & 97.42 & 1.51 & 2.29 \\
\hline Handerson \& Pabis & 87.05 & 2.93 & 8.61 \\
\hline Two Terms & 92.85 & 3.08 & 9.51 \\
\hline Polynomial & 99.62 & 0.71 & 0.50 \\
\hline \multicolumn{4}{|l|}{ T3 } \\
\hline Page & 98.68 & 0.97 & 0.94 \\
\hline Linear & 98.88 & 0.80 & 0.64 \\
\hline Modified Page & 98.68 & 0.97 & 0.94 \\
\hline Logarithm & 99.73 & 0.51 & 0.26 \\
\hline Handerson \& Pabis & 94.33 & 2.00 & 4.01 \\
\hline Two Terms & 97.88 & 1.73 & 3.00 \\
\hline Polynomial & 99.76 & 0.58 & 0.34 \\
\hline \multicolumn{4}{|l|}{ T4 } \\
\hline Page & 97.98 & 1.27 & 1.62 \\
\hline Linear & 96.70 & 1.46 & 2.12 \\
\hline Modified Page & 97.98 & 1.27 & 1.62 \\
\hline Logarithm & 99.15 & 0.96 & 0.92 \\
\hline Handerson and Pabis & 94.59 & 2.08 & 4.35 \\
\hline Two Terms & 94.59 & 2.95 & 8.69 \\
\hline Polynomial & 99.41 & 0.98 & 0.95 \\
\hline
\end{tabular}

either using commercial waxes or coating mixtures on the TS and SS levels of juices from any of the varieties tested in the study.

The SS content of control and coated fruits showed an increasing trend, which may be related to the mass loss of fruits. The behavior of soluble solids observed in this study corroborates with the results obtained by Nascimento et al. (2011) and Obenland et al. (2011).

\section{Turgidity pressure and mass loss evaluation}

Firmness is a critical quality attribute for consumer acceptability. Coated fruits showed significant turgor values compared to control fruits during the study period. Pectin coatings had a beneficial effect on fruit firmness so that at the end of the storage period, all treatments led to higher fruit firmness values compared to control fruits ( $p$ $=0.05$ ) (Table 2).

In general, coated fruits showed higher firmness values over the storage time, and treatments $\mathrm{T} 3$ and $\mathrm{T} 4$ were the most efficient; however, at the end of the storage period, treatment T2 showed peel stiffness, which is not related to turgidity pressure, but rather to a physiological disorder by $\mathrm{CO}_{2}$ accumulation promoted by atmosphere modification, water loss and high variability of fruits used. 

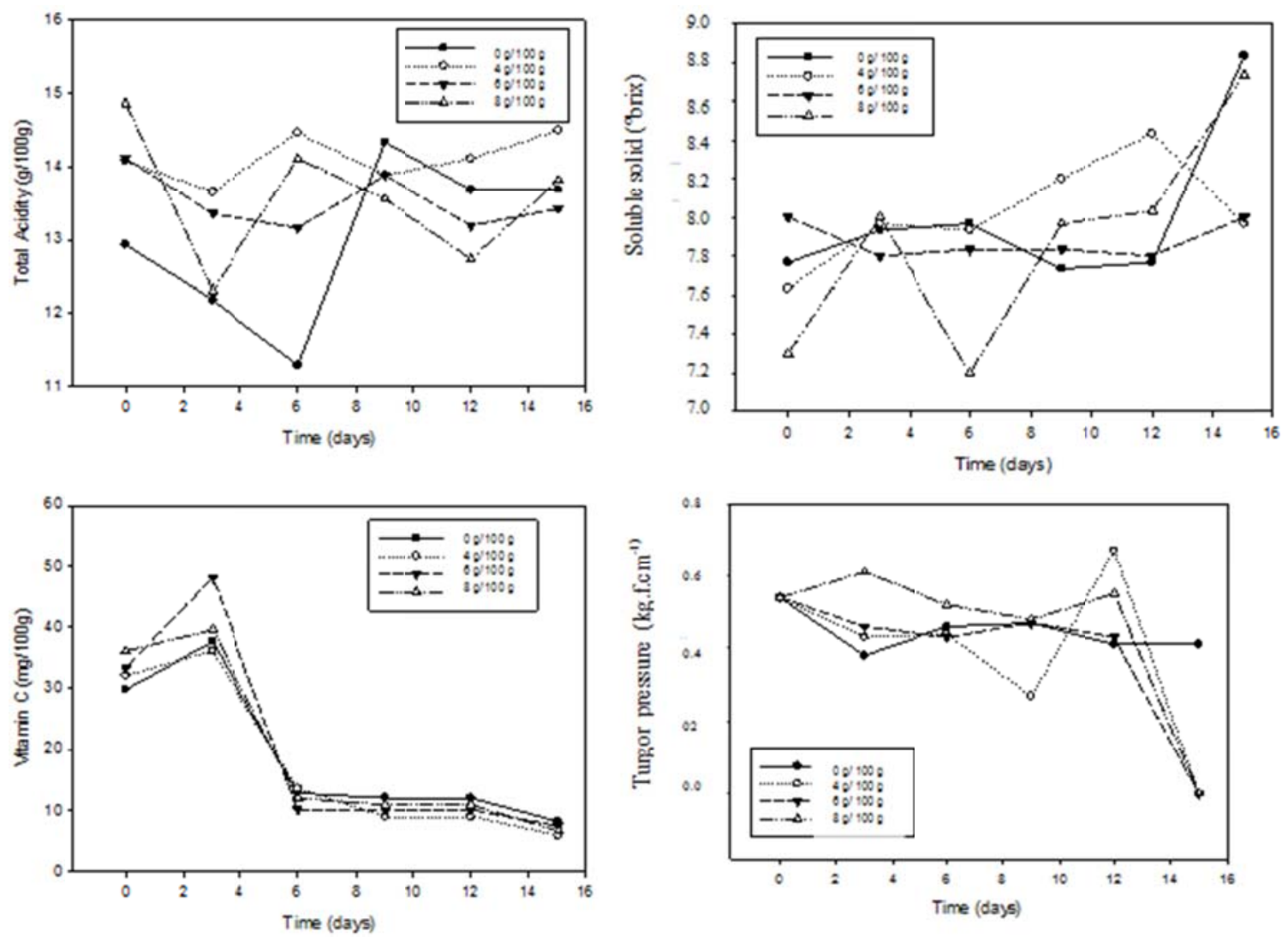

Figure 1. Titratable acidity $(\mathrm{g} / 100 \mathrm{~g})$, solubles solids, vitamin $\mathrm{C}$ and turgor pressure of tangerine coated with pectin -based biofilm stored at $22^{\circ} \mathrm{C}$.

Arnon et al. (2014) reported on studies with different citrus that the modification of the internal atmosphere of fruits causes $\mathrm{CO}_{2}$ accumulation and can stimulate anaerobic respiration. Table 2 shows the $R^{2}, x^{2}$ and SE values. By analyzing the determination coefficient, it turns out that the polynomial model obtained the highest values for all treatments and Two Terms and Henderson and Pabis models showed the lowest values. According to Doymaz (2012), the determination coefficient is one of the main criteria for the selection of the model that best fits the drying process; however, in addition to $R^{2}$, parameters SE and $X^{2}$ are used to determine the fitness quality. Analyzing the average deviation of the estimate (SE), all models showed low values; however, the polynomial model $\left(P M=\mathrm{k}_{0}+\mathrm{k}_{1} \cdot \mathrm{t}+\mathrm{k}_{2} \cdot \mathrm{t}^{2}+\mathrm{k}_{3} \cdot \mathrm{t}^{3}\right)$ showed the lowest values for all treatments. According to Draper and Smith (1981), the ability of a model to adequately represent a given physical process is inversely proportional to the mean deviation of the estimate. Table 2 also showed that through the chi-square test, it appears that only Two Terms and Henderson and Pabis models for the control treatment (T1) showed calculated chisquare values higher than tabulated values $\left(\mathrm{X}^{2}\right.$ tabulated $=$ 11.070), which discards the use of these models for the representation of this phenomenon. The polynomial model showed the lowest chi-square values for all treatments. Günhan et al. (2005) point out that the lower the chi-square value, the better the model fits the study phenomenon.

According to the criteria adopted, the polynomial model was chosen to represent the mass loss process of stored coated fruits because this model was the one that best suited to all treatments. Togrul and Aslan (2004) worked with tangerines coated with carboxy methyl cellulose and concluded that the polynomial model was the most suitable to represent the fruit mass loss. Figure 3 shows the mass loss versus storage time of fruits coated with different pectin concentrations adjusted by the polynomial model. The mass loss analysis allowed verifying the effectiveness of coatings in delaying the loss of water from fruits. The beneficial effects of fruit coatings included improved appearance and reduced mass loss. Machado et al. (2012) reported that there is a highly significant interaction between coatings and shelf life of fruits, reducing their mass loss. Shi et al. (2013) evaluated the effect of coatings on postharvest longan fruits and concluded that coatings significantly reduced the mass loss of fruits. Mathematical models describe mass loss as a function of storage time. Experimental data are closely linked to data estimated by the polynomial model, which 

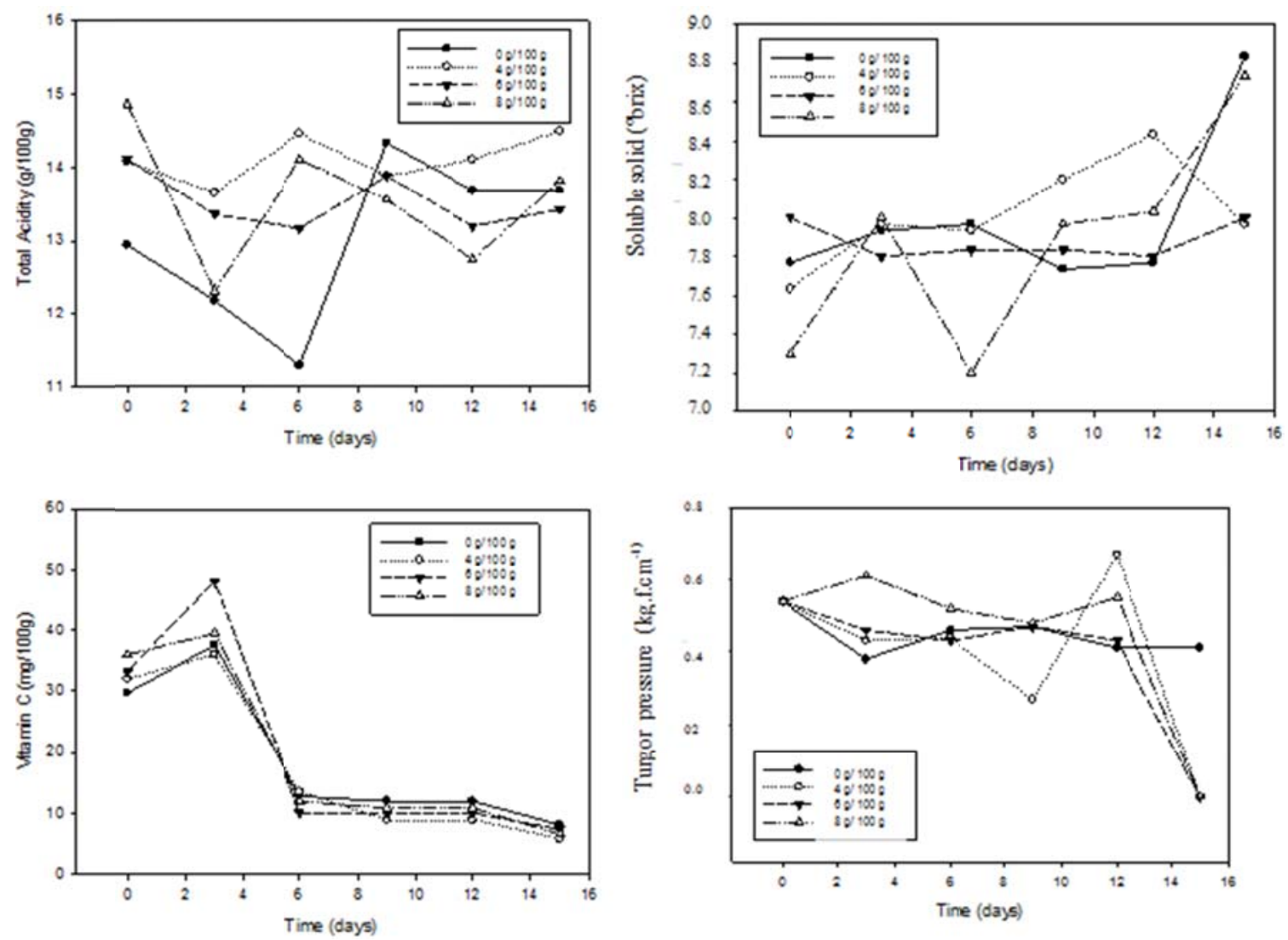

Figure 2. Titratable acidity ( $\mathrm{g} / 100 \mathrm{~g}$ ), solubles solids, vitamin $\mathrm{C}$ and turgor pressure of tangerine coated with pectin based biofilm stored at $22^{\circ} \mathrm{C}$.

Table 3. Polynomial model fitted to experimental data of mass loss during storage.

\begin{tabular}{cc}
\hline Treatment & Polynomial model \\
\hline T1 & $P M=-0.2350+2.6209 t-0.0922 \mathrm{t}^{2}+0.0029 \mathrm{t}^{3}$ \\
T2 & $P M=-0.1780+2.4570 \mathrm{t}+0.8916 \mathrm{t}^{2}+0.4155 \mathrm{t}^{3}$ \\
T3 & $P M=-0.1359+0.8916 \mathrm{t}+0.0473 \mathrm{t}^{2}-0.0012 \mathrm{t}^{3}$ \\
T4 & $P M=-0.0505+0.4155 \mathrm{t}+0.1183 \mathrm{t}^{2}-0.0036 \mathrm{t}^{3}$ \\
\hline
\end{tabular}

indicates the suitability of the model to describe the mass loss of fruits with and without coating. Table 3 presents the polynomial equations with constants obtained for the mass loss process. Constant "k" is related to water loss rate during storage processes and coatings, as barriers against water loss, influence the "k" values. By analyzing data, it was observed that constant "k" decreases in absolute values with increasing pectin concentrations in fruits, a fact expected, since higher coating concentrations lead to less transfer of water to the environment.

\section{Colorimetric analysis}

Luminosity or $L$ * represents the brightness of the fruit surface. Increase in $L^{*}$ value is related to fruit ripening, and coatings, as barriers to gas exchange, slow biochemical reactions of chlorophyll degradation, reducing ripening and therefore increasing the $L$ * values. Significant difference $(p=0.05)$ between treatments was observed for all parameters.

By analyzing the luminosity values of fruits during the storage period (Figure 3 ), it was observed that pectin coatings influenced gradually with concentrations used. Fruits coated with $8 \mathrm{~g} / 100 \mathrm{~mL}$ of pectin showed smaller $L$ * values, a fact related to chlorophyll preservation. Importantly, fruits with more attractive features are better marketed. Asgar et al. (2010) worked with tomatoes coated with gum Arabic and concluded that fruits kept luminosity values stable during storage. Asgar et al. (2011) reported that papaya fruits coated with higher chitosan concentrations obtained slower changes in 

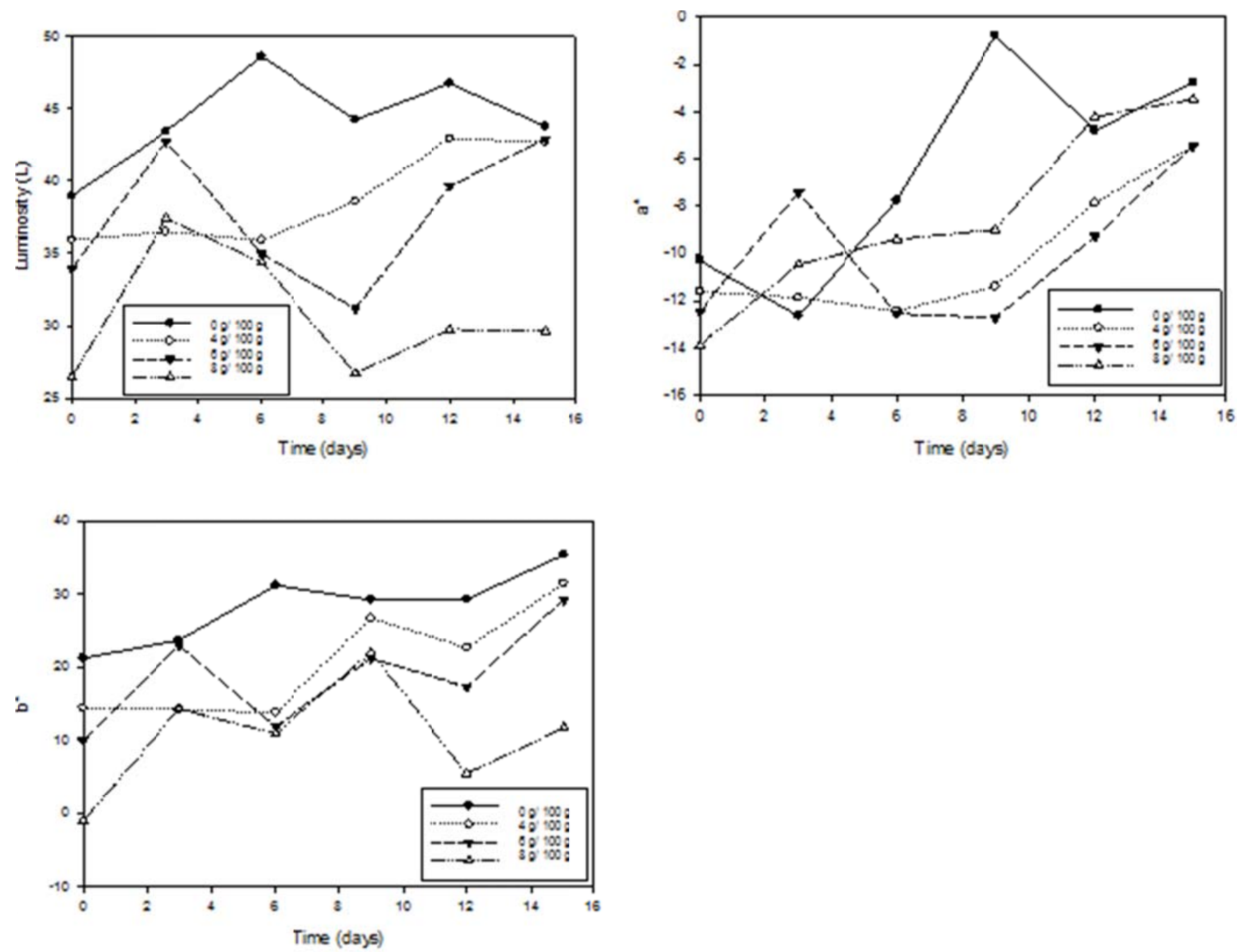

Figure 3. Luminosity $\left(L^{*}\right)$, green intensity $\left(-a^{*}\right)$ and yellow intensity $\left(+b^{*}\right)$ of tangerine peels coated with pectin-based biofilm stored at room temperature.

the $L$ * variable, corroborating the present work. RojasGrau et al. (2009) observed that chitosan-based coatings decreased the browning of pears during storage because the biofilm forms a barrier against gas exchange. In general, pectin-based treatments influence variable $a$ * up to the fifteenth day, being therefore effective to keep the green color of fruits. During ripening, tangerine peel goes from green to yellow, which is related to chlorophyll degradation and revelation of carotenoids (Jacomino et al., 2008). Alvares et al. (2003) found a variation of coordinate $-a^{*}$, which defines the green color in bananas (Ribeiro, 2006). The yellow intensity $\left(+b^{*}\right)$ of fruit peel presented in Figure 3 showed great variance throughout the storage period for Control fruits and for treatments T2 and T3, and revealed a significant increase in the yellow color of fruits. The advancement in the $b$ * values is the sign of maturation of fruits, with great influence for marketing. For fruits with higher pectin concentration $(8 \mathrm{~g}$
/ $100 \mathrm{~mL}$ ), the advancement in $b^{*}$ values was less expressive and it could be inferred that the pectin concentration was enough to prevent the "yellowing" of fruits. Chroma is the relationship between $a{ }^{*}$ and $b$ * values, in which the real color of the object being analyzed is obtained. The results of the chroma parameter corroborate the $b$ * results, in which control and treated fruits had $4 \mathrm{~g} / 100 \mathrm{ml}$ and $6 \mathrm{~g} / 100 \mathrm{~mL}$ pectin, with significant values for yellow color and fruits with $8 \mathrm{~g} \mathrm{/} 100 \mathrm{~mL}$ pectin, keeping color green. Statistically, at the beginning of the storage period, treatments can be considered equal, with variability occurring from the third day. The statistical difference for fruits with $8 \mathrm{~g} / 100 \mathrm{~mL}$ pectin over time is much less pronounced when compared to other treatments, and it could be concluded that fruits maintained green color over the storage period. Maftoonazad and Ramaswamy (2005) studied postharvest avocados and reported that 
coated fruits showed a slower rate of change in peel color. Ali et al. (2010) reported that coated tomatoes were greener even after 20 days of storage compared to control.

\section{Conclusion}

Mathematical models are suited to fruit mass loss, being useful tools to describe the mass loss during storage. The polynomial model best fitted to experimental data. The use of pectin-based coatings reduced the fruit mass loss. Fruits coated with $8 \mathrm{~g} / 100 \mathrm{ml}$ pectin can be stored for 15 days at $22^{\circ} \mathrm{C}$. The results presented confirm the beneficial effect of pectin films in postharvest conversation of tangerine fruits. Coatings are a simple, environmentally friendly and relatively inexpensive way to extend the shelf life of tangerine fruits.

\section{Conflict of Interests}

The author(s) have not declared any conflict of interests.

\section{ACKNOWLEDGEMENTS}

To the Foundation for Research Support of the State of Goiás (FAPEG) for the financial support to this project and the Coordination of Improvement of Higher Education Personnel (CAPES) for granting the scholarship Postdoctoral on the second and fourth authors.

\section{REFERENCES}

Ali A, Maqbool M, Ramachandran S, Alderson, PG (2010). Gum Arabic as a novel edible coating for enhancing shelf-life and improving postharvest quality of tomato (Solanumlycopersicum L.) fruit. Postharvest Biol. Technol. 58 42-47.

Alleoni ACC, Jacomino AP, Rosa AS (2006). Recobrimento de laranja 'Pêra' com filme de concentrado protéico de soro de leite associado a plastificantes. Revista Agropecuária Brasileira 4:1221-1226.

Álvares VS, Corrêa PC, Vieira G, Finger FL, Agnesini RV (2003). Análise da coloração da casca de banana prata tratada com etileno exógeno pelo método química e instrumental. Revista Brasileira de Produtos Agroindustriais 5:155-160.

AOAC, Official Methods of Analysis (1997). AOAC International, Gaithersburg, MD.

AOAC, Official Methods of Analysis (2005). AOAC International, Gaithersburg, MD.

Asgar A, Maqbool M, Alderson PG, Zahid N (2010). Gum Arabic as a novel edible coating for enhacing shelf-life and improving postharvest quality of tomato (Solanumlycopersicum L.) fruit. Postharvest Biol. Technol. 58:42-47.

Asgar A, Muhammad MTM, Sijam K, Siddiqui Y (2011). Effect of chitosan coatings on the physicocheminal characteristics of Eksotika II papaya (Carica papaya L.) fruit during cold storage. Food Chem. 124:620-626.

Azeredo HMC, Miranda KWE, Ribeiro HL, Rosa MF, Nascimento DM (2012). Nanoreinforced alginate-acerolapuree coatings on acerola fruits. J. Food Eng. 113:505-510.
Blum J, Hoffmann FB, Ayub RA, Jung DL, Malgarim MB (2008). Uso de cera na conservação pós-colheita do caqui cv. Giombo. Rev. Bras. Frutic. 30:830-833.

Calbo AG, Nery AA (1995). Medida de firmeza em hortaliças pela técnica da aplanação. Horticultura Brasileira, Brasília 12:14-18.

Chitarra MIF, Chitarra AB (2005). Pós-colheita de frutas e hortaliças: fisiologia e manuseio 2:785.

Chiumarelli M, Ferreira MD (2006). Qualidade pós-colheita de tomates 'Débora' com utilização de diferentes coberturas comestíveis e temperaturas de armazenamento. Hortic. Bras. 24.

Christensen SH (1984). "Pectins", in: Food Hydrocolloids, Glicksman M.

Doymaz I (2012). Evaluation of some thin-layer drying models of persimmon slices (diospyros kaki L.). J. Energy Convers. Manage. 56, 199-205.

Draper NR, Smith H (1998). Applied regression analysis.: John Wiley \& Sons. 3:712.

Gancz K, Alexander M, Corredig M (2006). Food Hydrocolloid, 20 ed., 293.

Günhan T, Demir V, Hancioglu E, Hepbasli, A (2005) Mathematical modelling of drying of bay leaves. Energy Convers. Manage. 46:1667-1679.

Henrique CM, Cereda MP, Sarmento SBS (2008). Características físicas de filmes biodegradáveis produzidos a partir de amidos modificados de mandioca. Ciência e Tecnologia de Alimentos 28: 231-240.

IBGE (Instituto Brasileiro de Geografia e Estatística) - Produção agrícola municipal: culturas temporárias e permanentes. Rio de Janeiro, 2012. 31:133.

Jacomino AP, Arruda MC, Bron IU, Kluge RA (2008). Transformações bioquímicas em produtos hortícolas após a colheita. In: KOBLITZ M G. B. (Coord.). Bioquímica de alimentos - teoria e aplicações práticas. Rio de Janeiro: Guanabara Koogan. pp. 153-189.

Lemos OL, Rebouças TNH, José ARS, Vila MTR, Silva KS (2007). Utilização de biofilme comestível na conservação de pimentão 'Magali R' em duas condições de armazenamento. Revista Bragantia 66.

Machado FLC, Costa JMC, Batista EM (2012). Applicationofcarnaubabasedwaxmaintainspostharvestqualityof ' Ortanique' tangor. Ciência e Tecnologia de Alimentos 32:261-266.

Maftoonazad N, Ramaswamy HS (2005). Postharvest shelf-life extension of avocados using methyl cellulose-based coating. LWT Food Sci. Technol. 38:617-624.

Miguel ACA, Dias JRPS, Silvana Albertini S, Spoto MHF (2009). Póscolheita de uva 'Itália' revestida com filmes à base de alginato de sódio e armazenada sob refrigeração. Ciência e Tecnologia de Alimentos 29:277-282.

Nascimento ET, Perez-Maluf R, Guimaraes RA, Castellani MA (2010). Diversidade de abelhas visitantes das flores de citrus em pomares de laranjeira e tangerineira. Rev. Bras. Frutic. 33:111-117.

Nascimento LM, Arruda MC, Fischer IH, Ferraz LP, Fonseca MB (2011). Potencial de conservação de tangerina W Murcott: armazenamento refrigerado $x$ atmosfera modificada. Citrus Res. Technol. 32:167-172.

Obenland D, Collin S, Mackey B, Sievert J, Arpaia ML (2011). Storage temperature and time influences sensory quality of mandarins by altering soluble solids, acidity and aroma volatile composition. Postharvest Biol. Technol. 59:187-193.

Oliveira DM, Rosa CILF, Kwiatkowski A, Clemente E (2013). Biodegradable coatings on the postharvest of blackberry stored under refrigeration. Revista Ciência Agronômica 44:302-309.

Oliveira ENA, Martins JN, Santos DC, Gomes JP, Almeida FAC (2012) Armazenamento de tomates revestidos com pectina: avaliação colorimétrica. Revista Caatinga 25:19-25.

Ribeiro DM (2006). Evolução das propriedades físicas, reológicas e químicas durante o amadurecimento da banana "prata-anã". 2006. 126 f. Tese (doutorado em Engenharia Agrícola) - Universidade Federal de Viçosa. Viçosa - MG.

Rojas-Graü MA, Rojas-Graü MAG, Oms-Oliu G, Soliva-Fortuny RO, Martín-Belloso $O$ (2009). The use of packaging techniques to maintain freshness in fresh-cut fruits and vegetables: a review. Int. J. Food Sci. Technol. 44:875-889.

Scalon SPQ, Oshiro AM, Dresch DM (2012). Conservação pós-colheita 
de guavira (CampomanesiaadamantiumCamb.) sob diferentes revestimentos e temperaturas de armazenamento. Rev. Bras. Frutic. 34:1022-1029.

Shi S, Wang W, Liu L, Wu S, Wei Y, Li, W (2013). Effect of chitosan/nano-silica coating on the physicochemical characteristics of longan fruit under ambient temperature. J. Food Eng. 118:125-131.

Souza CO, Silva LT, Druzian JI (2012). Estudo comparativo da caracterização de filmes biodegradáveis de amido de mandioca contendo polpas de manga e de acerola. Quím. Nova 35:262-267.

Thibault JF (1980). "Les substances pectiques", in: Les polymeresvegetaux, Monties B. (ed.), Gaulthier-Vilars, Paris.
Togrul H, Arslan N (2004). Carboxymethyl cellulose from sugar beet pulp cellulose as a hydrophilic polymer in coating of mandarin. $\mathrm{J}$. Food Eng. 62:271-279.

Valencia-Chamorro SA, Palou L, Río MA, Pérez-Gago MB (2011). Performance of hydroxypropyl methylcellulose (HPMC)-lipid edible coatings with antifungal food additives during cold storage of 'Clemenules' mandarins. LWT Food Sci. Technol. 44:2342-2348. 